\title{
THE GENUS CHELIDONURA AND A NEW SPECIES, C. TSURUGENSIS, FROM JAPAN
}

\section{$\operatorname{AUTHOR}(\mathrm{S})$ :}

Baba, Kikutaro; Abe, Takeo

\section{CITATION:}

Baba, Kikutaro ...[et al]. THE GENUS CHELIDONURA AND A NEW SPECIES, C.

TSURUGENSIS, FROM JAPAN. PUBLICATIONS OF THE SETO MARINE BIOLOGICAL LABORATORY 1959, $7(2):$ 279-280

ISSUE DATE:

1959-05-30

URL:

http://hdl.handle.net/2433/174605

RIGHT: 


\title{
THE GENUS CHELIDONURA AND A NEW SPECIES, C. TSURUGENSIS, FROM JAPAN ${ }^{1)}$
}

\author{
Kikutaro BABA and TAKeo ABE \\ Biological Laboratory, Osaka Gakugei University; \\ Takaoka High School, Takaoka, Toyama Pref.
}

With 2 Text-figures

The following is a list of the species of the genus Chelidonura known from the Japanese waters.

1. Chelidonura hirundinina (Quoy \& GaImard, 1832). Nishiki-tsubamegai.

Loc.: Hayama and Misaki, Sagami Bay ; Kii ; Okawa, Osaka Bay ; Sado I. ; Usetsu and Ogi, Toyama Bay; Togi Kazanashi, w. coast of Noto Peninsula ; Myojinzaki Mizushima, Tsuruga Bay ; Takarajima, Tokara group.

Dist.: Indian Ocean; Australia; N. Caledonia ; Bonin Is.

2. Chelidonura fulvipunctata $\mathrm{BABA}, 1938$. Akaboshi-tsubamegai.

Loc.: Shimoda ; Kii.

3. Chelidonura inornata BABA, 1949. Ohaguro-tsubamegai.

Loc.: Hayama, Sagami Bay.

Dist.: Bonin Is.

The following is here added to the above list.

\section{Chelidonura tsurugensis $\mathrm{BABA} \& \mathrm{ABE}, \mathrm{n} . \mathrm{sp}$. \\ Myojin-tsubamegai (n. n.)}

(Figs. 1-2)

Animals $15-20 \mathrm{~mm}$ in total length. Mantle-shield bifurcated behind, the left lobe long and tapering, the right one in all specimens shorter and rounded. General bodycolour a glossy purplish black. The whole upper surface except the sole is covered with a varying number of yellow or golden-yellow spots, very irregular in size and in arrangement. An opaque white marking at the anterior edge of the head-shield on each side. Parapodial lobes without a coloured border.

1) Contributions from the Seto Marine Biological Laboratory, No. 326.

Publ. Seto Mar. Biol. Lab., VII (2), 1959. (Article 14) 
Loc.: Myojinzaki Mizushima, Tsuruga Bay, under stones in the shallow water (July 1956, many sps.).

There are about twelve species and two varieties in the genus Chelidonura of the world (see Marcus, 1955, pp. 100-101). Our species comes nearest to C. hirundinina

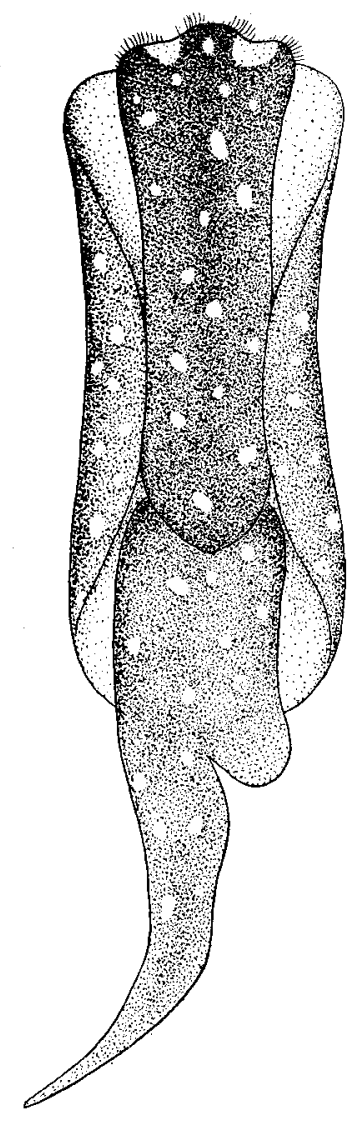

Fig. 1. Chelidonura tsurugensis (Tsuruga Bay, July 30, 1956, total length $20 \mathrm{~mm}$ ).
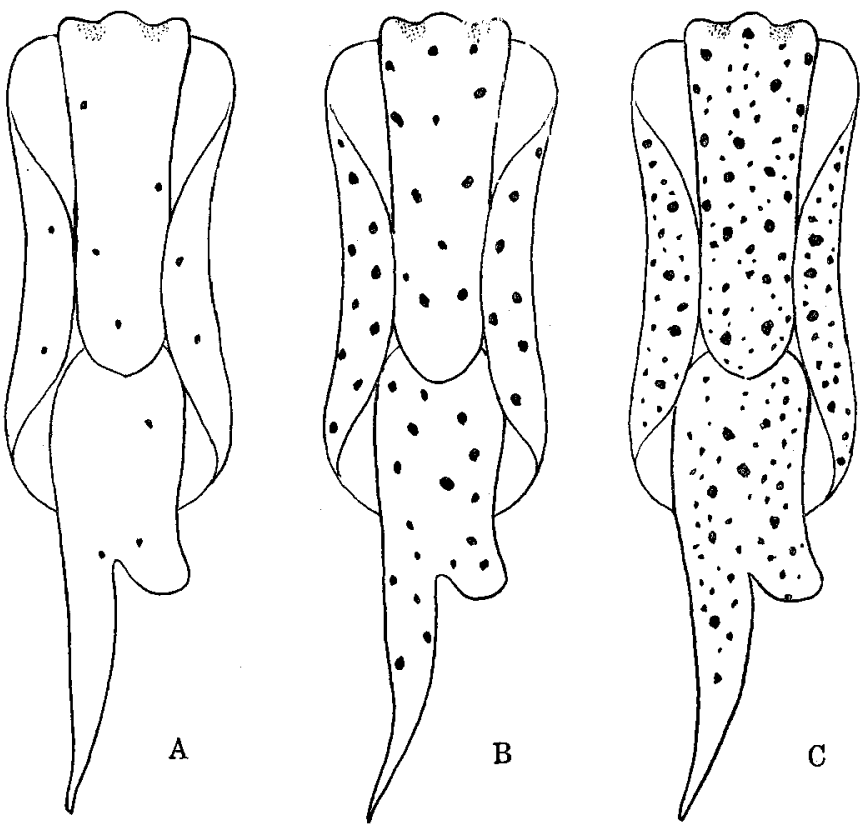

Fig. 2. Chelidonura tsurugensis. Distribution of the golden-yellow spots in different individuals, B. normal.

(Q. \& G.), var. punctata ELIOT from Zanzibar, but the latter form is especially marked by large, well-defined, orange spots rather regularly set on the body (see ELIOT, 1903, p. 336, pl. 13, fig. 2). Also our species cannot be confounded with C. fulvipunctata BABA in the detail of colouring.

\section{REFERENCES}

BABA, K. 1938. Opisthobranchia of Kii, Middle Japan. Journ. Dept. Agric. Kyusyu Imp. Univ., vol. 6 , no. 1 .

1949. Opisthobranchia of Sagami Bay. Iwanami Shoten, Tokyo.

Eliot, C. 1903. Notes on some new or little-known members of the family Doridiidae. Proc. Malac. Soc. London, vol. 5.

Marcus, E. 1955. Opisthobranchia from Brazil. Bol. Fac. Fil. Ciên. Letr., Univ. São Paulo, Zoologia, no. 20. 